"Factors affecting accrual accounting reform and transparency of performance in the public sector in Vietnam"

\begin{tabular}{|c|c|}
\hline \multirow{5}{*}{ AUTHORS } & Phuong-Nguyen Thi Thanh (D) https://orcid.org/0000-0003-4544-3182 \\
\hline & Hai Phan Thanh (D https://orcid.org/0000-0003-2176-9153 \\
\hline & R http://www.researcherid.com/rid/P-4732-2018 \\
\hline & Tung-Nguyen Thanh \\
\hline & Tien-Vo Thi Thuy \\
\hline ARTICLE INFO & $\begin{array}{l}\text { Phuong-Nguyen Thi Thanh, Hai Phan Thanh, Tung-Nguyen Thanh and Tien-Vo } \\
\text { Thi Thuy (2020). Factors affecting accrual accounting reform and transparency of } \\
\text { performance in the public sector in Vietnam. Problems and Perspectives in } \\
\text { Management, 18(2), 180-193. doi:10.21511/ppm.18(2).2020.16 }\end{array}$ \\
\hline DOI & http://dx.doi.org/10.21511/ppm.18(2).2020.16 \\
\hline RELEASED ON & Tuesday, 02 June 2020 \\
\hline RECEIVED ON & Saturday, 07 March 2020 \\
\hline \multirow[t]{2}{*}{ ACCEPTED ON } & Friday, 22 May 2020 \\
\hline & $(\mathrm{ccc}) \mathrm{EY}$ \\
\hline LICENSE & $\begin{array}{l}\text { This work is licensed under a Creative Commons Attribution } 4.0 \text { International } \\
\text { License }\end{array}$ \\
\hline JOURNAL & "Problems and Perspectives in Management" \\
\hline ISSN PRINT & $1727-7051$ \\
\hline ISSN ONLINE & $1810-5467$ \\
\hline PUBLISHER & LLC "Consulting Publishing Company "Business Perspectives" \\
\hline FOUNDER & LLC "Consulting Publishing Company "Business Perspectives" \\
\hline
\end{tabular}

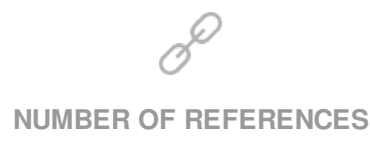

35
NUMBER OF FIGURES

3
NUMBER OF TABLES

8

(C) The author(s) 2023. This publication is an open access article. 




\section{BUSINESS PERSPECTIVES}

LLC "CPC "Business Perspectives" Hryhorii Skovoroda lane, 10, Sumy, 40022, Ukraine www.businessperspectives.org
Received on: $7^{\text {th }}$ of March, 2020 Accepted on: 22nd of May, 2020 Published on: $2^{\text {nd }}$ of June, 2020

(C) Phuong-Nguyen Thi Thanh, HaiPhan Thanh, Tung-Nguyen Thanh, Tien-Vo Thi Thuy, 2020

Phuong-Nguyen Thi Thanh, Ph.D., Lecturer, Thuongmai University, Hanoi city, Vietnam.

Hai-Phan Thanh, Ph.D., Associate Professor, Dean, Faculty of Accounting, Institute of Research and Development, Duy Tan University, Vietnam. (Corresponding author)

Tung-Nguyen Thanh, MA, Lecturer, Faculty of Economics, Binh Duong University, Binh Duong city, Vietnam.

Tien-Vo Thi Thuy, MA, Lecturer, VNUK Institute for Research and Executive Education, University of Danang, Vietnam.

Phuong-Nguyen Thi Thanh (Vietnam), Hai-Phan Thanh (Vietnam), Tung-Nguyen Thanh (Vietnam), Tien-Vo Thi Thuy (Vietnam)

\title{
FACTORS AFFECTING ACCRUAL ACCOUNTING REFORM AND TRANSPARENCY OF PERFORMANCE IN THE PUBLIC SECTOR IN VIETNAM
}

\begin{abstract}
This study was conducted to determine the factors and their influence on accrual accounting reform in the public sector in Vietnam. Combining qualitative and quantitative research methods based on empirical surveys of 268 accountants, controllers, and auditors working in state agencies such as the Department of Finance, state treasuries and agencies receiving revenues from the state budget in 2019. This study shows that six factors influence the reform of the accounting system in the public sector in Vietnam to accrual-based: accounting staff - especially their expertise, competence, and work experience; training and support of the consulting experts; costs of the accounting reform; level of information technology application; funding and assistance from international organizations; legal environment.
\end{abstract}

At the same time, the accrual-based accounting reform will have a positive impact on improving the transparency and efficiency of public sector operations in Vietnam. Among the factors affecting accounting reform, the legal environment factor is the most influential determinant, followed by the contingent of accountants. The study's limitation is that the new experimental investigation is only conducted with a small sample size and in a short period. However, the research results are also a useful reference for those who are interested in the context that Vietnam is preparing to have strong reforms in accounting in the public sector in the coming time.

Keywords

JEL Classification

\section{INTRODUCTION}

For every country, the public sector accounting system plays a very important role because it is a system of rules and application of principles, methods, and accounting guidelines, which organizations can rely on to prepare their financial reporting package, evaluate the fairness, accountability, and transparency of the financial status in public sectors. In Vietnam, the accounting system has a long time using a cash-based system and started to move forward to accrual-based since 2017. At the moment, in the public sector, Vietnam is still using the new Accounting Rules, and under the rules are the detailed guidelines for the specific agencies. During that time, Vietnam has been improving by issuing many accounting guidelines for public sectors, such as Accounting for the Administrative Agency (Circular No. 107/2017/TT-BTC), Accounting for the Province Budget (Circular No. 70/2019/TT-BTC), Accounting for State Budget and State Treasury (Circular No. 77/2017/TT-BTC). However, until now, Vietnam does not have a completed system of public sector accounting; instead, Vietnam just has a proposal for this system starting in 2021 (The Vietnam Ministry of Finance, 2019) 
Changing in the accounting system is considered as a reform in this sector, and this topic is widely discussed by many experts in Vietnam and over the world. Many studies show that the accounting reform moving toward accrual-based will improve the quality of financial reporting information, from that providing useful information in decision-making and taking responsibility. Changing the accounting system from cash-based to accrual-based in the public sector is needed in many countries; however, many factors will affect this process and make it impossible to execute. There are many studies about the factors leading to the accrual accounting reform, such as Lüder (1992), Ouda (2004, 2008), Chan (2005), Upping and Oliver (2011), Harun and Kamase (2012), Jovanović (2013), Nistor, Deaconu, and Mare (2014). There are also different researches about the factors affecting the accrual accounting reform, such as Eriotis, Stamatiadis, and Vasiliou (2011), HassabElnaby, Epps, and Said (2003), Nasi and Steccolini (2008), Alshujairi (2014), Harun and Robinson (2010), Peter van der Hoek (2005).

There are many studies on the improvement of the accounting system in the public sector from different authors during this time in Vietnam. Some of the outstanding ones are the improvement of the financial reporting for public agencies, using the international accounting standards (IPSAS) from Hong (2013), the improvement of the accounting system for government fund spending from Huy (2014), the improvement of financial reporting in the public sector from Hien (2015). Though there are many studies as mentioned, the research focused specifically on factors affecting on accounting standard from cash-based to accrual-based and the degree of their influence to Vietnam's public sector have not been done.

Therefore, this study is done based on these objectives:

a) evaluate the overall status of the studies on factors affecting accounting reform from cash-based to accrual-based accounting;

b) present the research model, the hypotheses in the model, and collecting data methods. Based on that, the authors perform a research on factors affecting accounting reform from cash-based to accrual-based in Vietnam's public sector;

c) present the conclusion and recommendations from the research.

\section{LITERATURE REVIEW AND HYPOTHESES DEVELOPMENT}

\subsection{The importance of public sector accounting reforms from cash- based accounting to accrual- based accounting}

Based on studies done in the past, most of the authors agreed that the accounting reform moving toward accrual-based accounting will help to improve the quality of financial reporting information, from that fulfill the need in providing useful information in decision-making and taking responsibility.

The research of Ouda (2004), if the accrual-based accounting reform for the public sector is performed successfully, will help to improve finan- cial reporting, improve the evaluation of financial reporting presentation of the government, better management on assets and liabilities. Carlin (2003) evaluated the pros and cons, as well as different views on accrual-based public sector accounting. He concluded that accrual accounting is critical and necessary in the future, and only accrual accounting is qualified with the objective of providing useful information for decision-making and taking responsibility in the public sector. Research on the actual situation of Australia showed that if the process of changing to accrual accounting is performed completely regarding all the costs associated with this process, the financial reporting will provide more useful information.

Before that, research of Lüder (1992) about the studies of the public sector accounting system from developed countries like the USA, Canada, Denmark, Germany, France, England, or a few other countries in Europe concluded that on- 
ly when the public sector's accounting system is moved to accrual accounting, the information provided to users is complete, useful, reliable, and be able to control the resources of public agencies. The study of Jorge (2003) about the accounting reform in Spain also showed that there are many benefits from the reform; however, some points need to be improved.

In the meantime, in Vietnam, the study of Hong (2013) showed that it is necessary to change the financial reporting for public agencies following the IPSAS, change the accounting system to accrual-based accounting completely, improve the accounting standards, issue the standards on internal control so that the accounting information in the public sector will become more useful for the stakeholders.

Huy (2014) determined that, in order for Vietnam to join the international convergence, it is necessary to issue and apply the accounting standards based on IPSAS, develop the convergence process from accounting process with model TABMIS to the country's GAAP, based on new rules on the government budget, budget control, and financial accounting system for each specific agency. Whereas, in the study of Hien (2015), it is determined that the financial reporting of the public sector in Vietnam is not providing useful information on the financial status, the performance, cash flow, and explanatory notes of the public agencies. There are still many drawbacks, such as the complexness of the forms and other standards. Therefore, there is a need to improve the quality of financial reporting in the public sector.

\subsection{Factors affecting the accounting reform from cash-based to accrual-based accounting in the public sector}

\subsubsection{The accounting staff}

The human factor is always the most important factor in many organizations in any industry or sector. Professional education level and the competency of the accounting staff play a very important role in the accounting reform. Alshujairi (2014) found that the main challenge in applying the IPSAS in Iraq is a human because they cannot understand and apply the standards. Besides, Ouda (2004) suggested a point that a high level of education from the staff will help them understand and apply the new accounting techniques in the organization. Research of Eriotis, Stamatiadis, and Vasiliou (2011) also agreed that accounting reform is positively associated with the education level of accounting department personnel. In Vietnam, Hien (2015) showed that a professional education environment, specifically the education level of the experts, accounting staff, recruiting, and training procedures in the public sector, have a great effect on the accounting reform. Based on the results of previous research, the hypothesis is formulated as follows:

H1: The accounting staff has a positive effect on the accrual accounting reform in the public sector.

\subsubsection{Training and professional support from the consulting experts}

Ouda (2004) suggested that the consulting experts are considered the main leverage in the process of changing management and improvement in the public sector, through their assistance on technical issues and knowledge. At the same time, Eriotis, Stamatiadis, and Vasiliou (2011) on accounting reform in public hospitals in Egypt found that the level of accounting reform application has a strong connection with the support from experts. Also, the level of accounting reform adoption is positively associated with the level of reform-related training for the accounting staff. Hien (2015) found a strong effect of the international environment, with the technical support of international experts on the accounting reform of the public sector in Vietnam. Based on the previous studies, the hypothesis is formulated as follows:

H2: The training and professional support from the consulting experts have a positive effect on the accounting reform in the public sector.

\subsubsection{Cost of the accounting reform}

Researches by many authors have shown that the accounting reform from cash-based accounting to accrual accounting is a costly process. Research by 
Alshujairi (2014) done by interviewing 3 groups of accountants, auditors, and budgetary planning staff showed that the most influential factor affecting the application of accrual accounting reform in Iraq is the financial support from the sponsors.

HassabElnaby, Epps, and Said (2003), Nasi and Steccolini (2008), Eriotis, Stamatiadis, and Vasiliou (2011), Harun and Robinson (2010) also agreed that the accrual accounting reform requires a huge fund for training. Hien (2015) found that the financial environment, especially the costs for reforming from cash-based accounting to accrual accounting through activities such as accounting software, improving the infrastructure, training fees, changing forms, books, have a great effect on the accounting reform in Vietnam. Based on the previous studies, the hypothesis is formulated as follows:

H3: Costs have a positive effect on the accrual accounting reform in the public sector.

\subsubsection{Level of the information technology application in accounting functions}

Many studies suggested that organizations with an advanced level of information technology can perform the new accounting systems compared to those with a lower level of IT due to lower cost of processing and measuring. The enterprise resource planning (ERP) system is considered as a centralized system that provides tight integration with all major enterprise functions, decreases the processing time, and increases quality assurance within the organization. (Scapens \& Jazayeri, 2003). For the public sector, the high-quality information technology level is the first and foremost condition to successfully perform the accounting reform or other improvements in the organization. This also helps to assist the application or adoption of accrual accounting reform in the public sector (Ouda, 2004).

Eriotis, Stamatiadis, and Vasiliou (2011) found that the quality of information technology has a positive effect on the accounting improvements in public hospitals in Egypt. At the same time, through the study on Iraq's actual situation, Alshujairi (2014) concluded that most of the accountants, auditors, and budgetary planning staff were afraid that the information technology application level was not high enough to apply the new accounting system followed the IPSAS standards. Hien (2015) also suggested that the education environment, especially the ability to apply information technology, greatly affects the accounting reform in Vietnam's public sector. Based on the previous studies, the hypothesis is formulated as follows:

H4: Level of information technology application in accounting functions has a positive effect on the accrual accounting reform in the public sector.

\subsubsection{Funding and assistance from international organizations}

In the developing process of each country, external factors such as funding and assistance from other organizations or other countries play a very important role. Ouda (2004, 2008), Chan (2005), Upping and Oliver (2011), Harun and Kamase (2012), Hien (2015) found that these international factors will affect the accounting reform in the public sector of many countries, especially developing countries. Strong funding and assistance from international organizations will help to push the accounting reform process and other accounting improvements. Based on the previous studies, the hypothesis is formulated as follows:

\section{H5: Funding and assistance from international organizations have a positive effect on the ac- crual accounting reform in the public sector.}

\subsubsection{Legal environment of the public sector}

Whether the accounting reform from cash-based accounting to accrual accounting can be done accordingly or not depends on the legal environment of each country. According to Hien (2015), the legal environment factors affecting the accounting reform include rules or standards on the transparency of the public sector's financial statements, the internal control system, the need for the use of information from different users, financial statements and objective of those statements in the public sector, rules and standards on the financial management of the public sector, other professional organizations, and the accounting 
standards issuing body. In the research of Hai et al. (2019), it is said that the legal environment has a positive effect on the functions and activities of accounting and auditing. Based on the previous studies, the hypothesis is formulated as follows:

H6: Legal environment has a positive effect on the accrual accounting reform in the public sector.

\subsection{The relationship between accrual accounting reform and the transparency and overall performance in the public sector}

There are many studies about the accrual accounting reform in the past such as Alijarde (1997), Ouda (2002), Paulsson (2006), Stamatiadis (2009), Lapsley, Mussari, and Paulsson (2009), Deaconu, Nistor, and Crina (2011), Lampe, Hilgers, and Ihl (2015), which all agreed that changing the accounting system from cash-based accounting to accrual accounting will improve the transparency, the financial responsibility, and the overall performance in the public sector. Based on the previous studies, the hypothesis is formulated as follows:
H7: Accrual accounting reform has a positive effect on the transparency and overall performance in the public sector.

\subsection{Conceptual model}

As mentioned above, combining the results from different researches, the authors suggest the model using for this research as follows:

\section{DATA AND RESEARCH METHODOLOGY}

\subsection{Collection of data}

This research is done to determine the factors affecting the accrual accounting reform and the effect of this reform on the transparency and overall performance of the public sector in Vietnam. The authors used the random sample selections by sending emails using Google Forms and sent a sample size of 300 questionnaires directly to the responders' addresses. However, due to different reasons, 268 completed and qualified questionnaires were returned. The rest of the question-

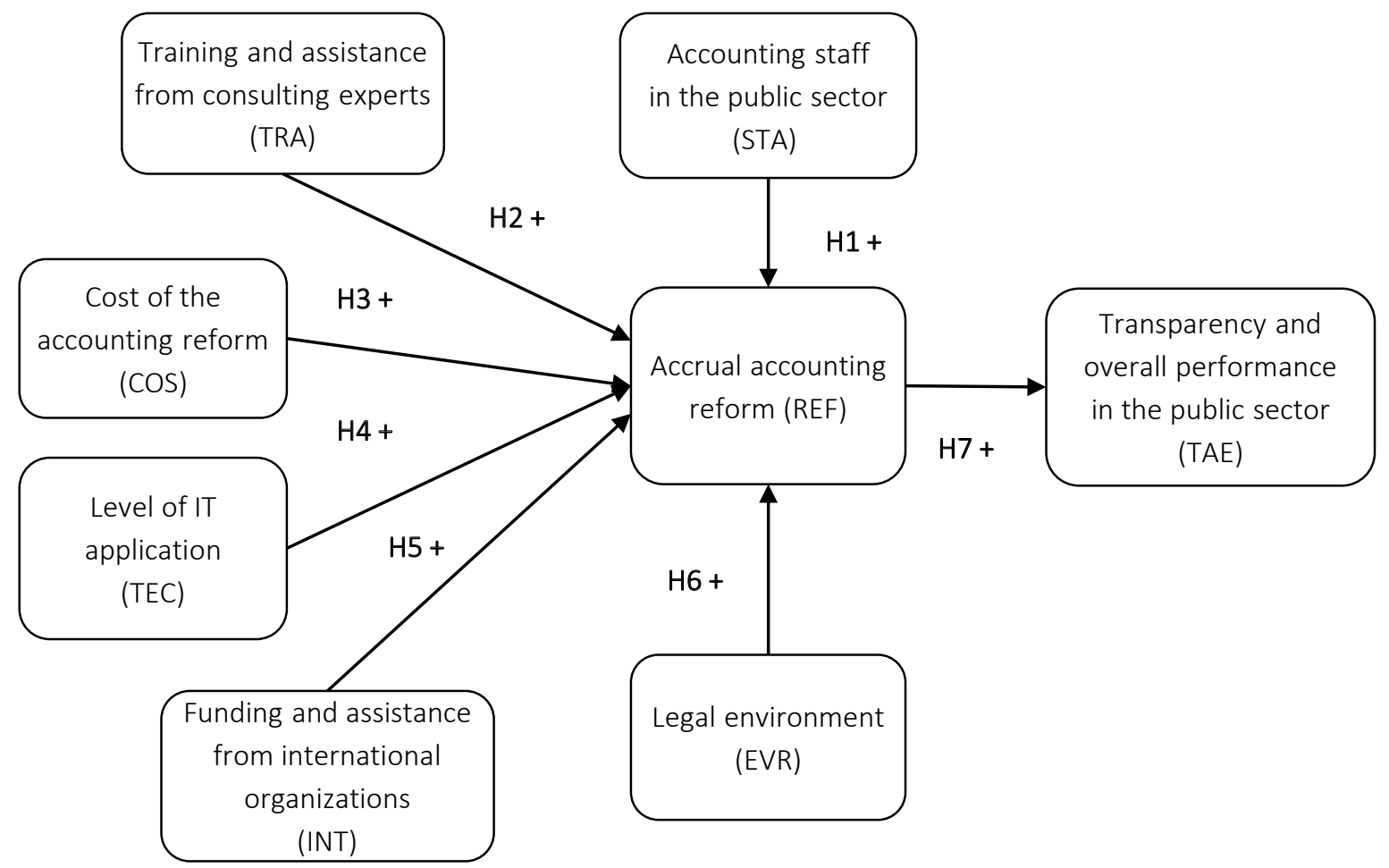

Figure 1. Conceptual model 
naires were either not answered or missing too much information. The time for data collection was from August to December 2019.

The respondents selected were those that work in the public sector and have been doing (or have related works with) accounting functions for at least 3 years. Therefore, the accountants and controllers working in the public sector such as the Department of Finance, state treasuries, Department of Taxation, Customs, and other state auditors, were chosen. Information about the respondents (268 people) is shown in Table 1.

Table 1. Demographic characteristics of respondents

Source: Authors' survey (2019).

\begin{tabular}{l|c:c}
\hline \multicolumn{1}{c}{ Characteristics } & Frequency & Percentage, \% \\
\hline Vocation & $N=268$ & 100 \\
\hline State auditors & 52 & 19.4 \\
\hline $\begin{array}{l}\text { Accountants and controllers } \\
\text { in the public sector }\end{array}$ & 216 & 80.6 \\
\hline Gender & $N=268$ & 100 \\
\hline Male & 112 & 41.7 \\
\hline Female & 156 & 58.3 \\
\hline Age & $N=268$ & 100 \\
\hline $28-35$ & 96 & 35.8 \\
\hline 36-45 & 85 & 31.7 \\
\hline 46-55 & 87 & 32.5 \\
\hline Education & $N=268$ & 100 \\
\hline College & 42 & 15.7 \\
\hline Bachelor & 145 & 54.1 \\
\hline Postgraduate & 81 & 30.2 \\
\hline
\end{tabular}

Besides, these 268 responders working in the public sector are from $20 / 63$ cities, provinces in Vietnam.

\subsection{Variables and measures}

Within this research, there are 2 types of variables: dependent and independent. The independent variables include Accounting staff in the public sector (STA) with 5 observations, Training and assistance from the consulting experts (TRA) with 5 observations, Cost of the accounting reform (COS) with 4 observations, Level of information technology application (TEC) with 4 observations, Funding and assistance from international organizations (INT) with 4 observations, Legal environment (EVR) with 5 observations. The dependent variables include Accrual accounting reform (REF) with 4 observations, Transparency and overall performance (TAE) with 5 observations. The dependent and independent variables are listed in the questionnaires, with a total of 8 variables and 36 observations, using Likert measurement scale with 5 levels (Level 1 - Absolutely disagree, Level 2 - Disagree, Level 3 - Undetermined between agree and disagree, Level 4 - Agree, Level 5 - Strongly agree). These measurements are observed and adjusted from previous studies, especially Hien (2015) and Eriotis, Stamatiadis, and Vasiliou (2011). After that, the authors perform the interviews of experts from the public sector (10 people) who currently are the managers with more than 20 years of working experience. After the adjustments from the observations, one processes to interview 2 groups with 10 state auditors and 10 accountants, controllers working in the public sector. Based on the initial analysis of 20 samples, the sample size was increased, and the interviews with a total of 300 questionnaires were performed. The results are 268 completed and qualified questionnaires.

\subsection{Analysis method}

The authors analyzed the effect of independent variables on the dependent variables using the combination of SPSS 20 software and AMOS.

With SPSS, measurement quality testing was performed using Cronbach's Alpha. The measurement scale is considered good when the overall CRA factor $>0.6$ and the corrected item total correlation > 0.3 (Nunnally, 1978; Peterson, 1994). All the measurement scales and observation variables are continued to perform Exploratory Factor Analysis (EFA).

In the EFA analysis, the compatibility testing was performed using Kaiser-Meyer-Olkin (KMO) measure. According to Hair, Black, Babin, Anderson, and Tatham (2006), when KMO is qualified from 0.5 to 1 , the analyzed factors are compatible. At the same time, the correlation testing of the observation variables in each scale was performed using the test of Barlett. When the significance (sig.) is less than or equal to 0.05 , then the variances are equal across groups or samples. Besides, the cumulative variance testing was also performed, which showed the percentage change in the factors explained by the observation variables. According to Anderson and Gerbing (1988), acceptable cumulative variance is greater than 
$50 \%$, eigenvalue is greater than 1 , and the factor loading with sample size less than 350 is greater than 0.55 .

Regarding the AMOS, the confirmatory factor analysis (CFA) and the structural equation modeling (SEM) were performed to determine if the measurement model is compatible with the actual data, testing with 7 hypotheses initially suggested. The statistic used to measure the compatibility level are Chi-square statistics (Cmin) $p$-value $>0.05$ (Hair, Black, Babin, Anderson, \& Tatham, 2006), Chisquare adjusted with the degree of freedom (Cmin/ df), $\chi^{2} / \mathrm{df}<5$ (Schumacker \& Lomax, 2004), the Comparative Fit Index (CFI) $>0.9$ (Hooper et al, 2008), the Tucker-Lewis Index (TLI) $>0.9$ (Hair, Black, Babin, Anderson, \& Tatham, 2006) and the Root Mean Square Error Approximation (RMSEA) < 0.08 (Schumacker \& Lomax, 2004; Hair, Black, Babin, Anderson, \& Tatham, 2006).

\section{RESULTS}

\subsection{Cronbach's Alpha testing}

Table 2. Test results of Cronbach's Alpha coefficients on scales

Source: Author's research (2019).

\begin{tabular}{|c|c|c|c|}
\hline Scales & Symbol & $\begin{array}{l}\text { Observed } \\
\text { variables }\end{array}$ & $\begin{array}{l}\text { Cronbach's } \\
\text { Alpha }\end{array}$ \\
\hline \multicolumn{4}{|c|}{ Independent variables } \\
\hline $\begin{array}{l}\text { Accounting staff in the } \\
\text { public sector }\end{array}$ & STA & 5 & 0.905 \\
\hline $\begin{array}{l}\text { Training and assistance } \\
\text { from the consulting } \\
\text { experts }\end{array}$ & TRA & 5 & 0.896 \\
\hline $\begin{array}{l}\text { Cost of the accounting } \\
\text { reform }\end{array}$ & $\cos$ & 4 & 0.856 \\
\hline $\begin{array}{l}\text { Level of the } \\
\text { information } \\
\text { technology application }\end{array}$ & TEC & 4 & 0.902 \\
\hline $\begin{array}{l}\text { Funding and assistance } \\
\text { from international } \\
\text { organizations }\end{array}$ & INT & 4 & 0.896 \\
\hline Legal environment & EVR & 5 & 0.898 \\
\hline \multicolumn{4}{|c|}{ Dependent variables } \\
\hline $\begin{array}{l}\text { The accrual accounting } \\
\text { reform }\end{array}$ & REF & 4 & 0.834 \\
\hline $\begin{array}{l}\text { The transparency and } \\
\text { overall performance }\end{array}$ & TAE & 5 & 0.942 \\
\hline
\end{tabular}

Test results from Cronbach's Alpha in Table 2 showed that the CRA factors of the dependent and independent variables are greater than 0.6 ; therefore, all 36 observations in the measurement scales are qualified to use in the next analysis.

\subsection{EFA and CFA analysis}

Table 3. Results of EFA test

Source: Author's research (2019)

\begin{tabular}{l|c:c:c:c}
\hline \multicolumn{1}{c}{ Scales } & KMO & Sig. & AVE (\%) & Eigenvalue \\
\hline $\begin{array}{l}\text { Independent } \\
\text { variables }\end{array}$ & 0.810 & 0.000 & 74.057 & 1.384 \\
\hdashline $\begin{array}{l}\text { Dependent } \\
\text { variables }\end{array}$ & 0.912 & 0.000 & 75.090 & 1.335 \\
\hline
\end{tabular}

According to the above analysis with $\mathrm{KMO}$, $p$-value, VAE, both the factor loading and eigenvalue factor are qualified. This shows that the factors used in this model, the observations in each measurement scales, and the changes of the factors explained by the variable are compatible.

Table 4. Composite reliability and variance extracted test

Source: Author's research (2019)

\begin{tabular}{|c|c|c|c|}
\hline Factors & Symbol & C.R. & AVE \\
\hline $\begin{array}{l}\text { Accounting staff in the } \\
\text { public sector }\end{array}$ & STA & 0.907 & 0.662 \\
\hline $\begin{array}{l}\text { Training and assistance } \\
\text { from the consulting experts }\end{array}$ & TRA & 0.887 & 0.617 \\
\hline $\begin{array}{l}\text { Cost of the accounting } \\
\text { reform }\end{array}$ & $\cos$ & 0.865 & 0.619 \\
\hline $\begin{array}{l}\text { Level of the information } \\
\text { technology application }\end{array}$ & TEC & 0.906 & 0.706 \\
\hline $\begin{array}{l}\text { Funding and assistance } \\
\text { from the international } \\
\text { organizations }\end{array}$ & INT & 0.893 & 0.684 \\
\hline Legal environment & EVR & 0.887 & 0.616 \\
\hline $\begin{array}{l}\text { The accrual accounting } \\
\text { reform }\end{array}$ & REF & 0.837 & 0.563 \\
\hline $\begin{array}{l}\text { The transparency and } \\
\text { overall performance }\end{array}$ & TAE & 0.943 & 0.769 \\
\hline
\end{tabular}

Based on Table 4, the composite reliability of all the factors is greater than 0.7 , and the AVE is greater than $50 \%$; therefore, one can conclude that the factors in our model are reliable.

This model has 564 degree of freedom (df), CFA shows the $p$-value $=0.000$; RMSEA $=0.042<0.08$; Chi-square $/ \mathrm{df}=1.474<5$; TFI $=0.958>0.9$; CFI $=0.962>0.9$. The results showed that the data are accepted with the suggested model. 


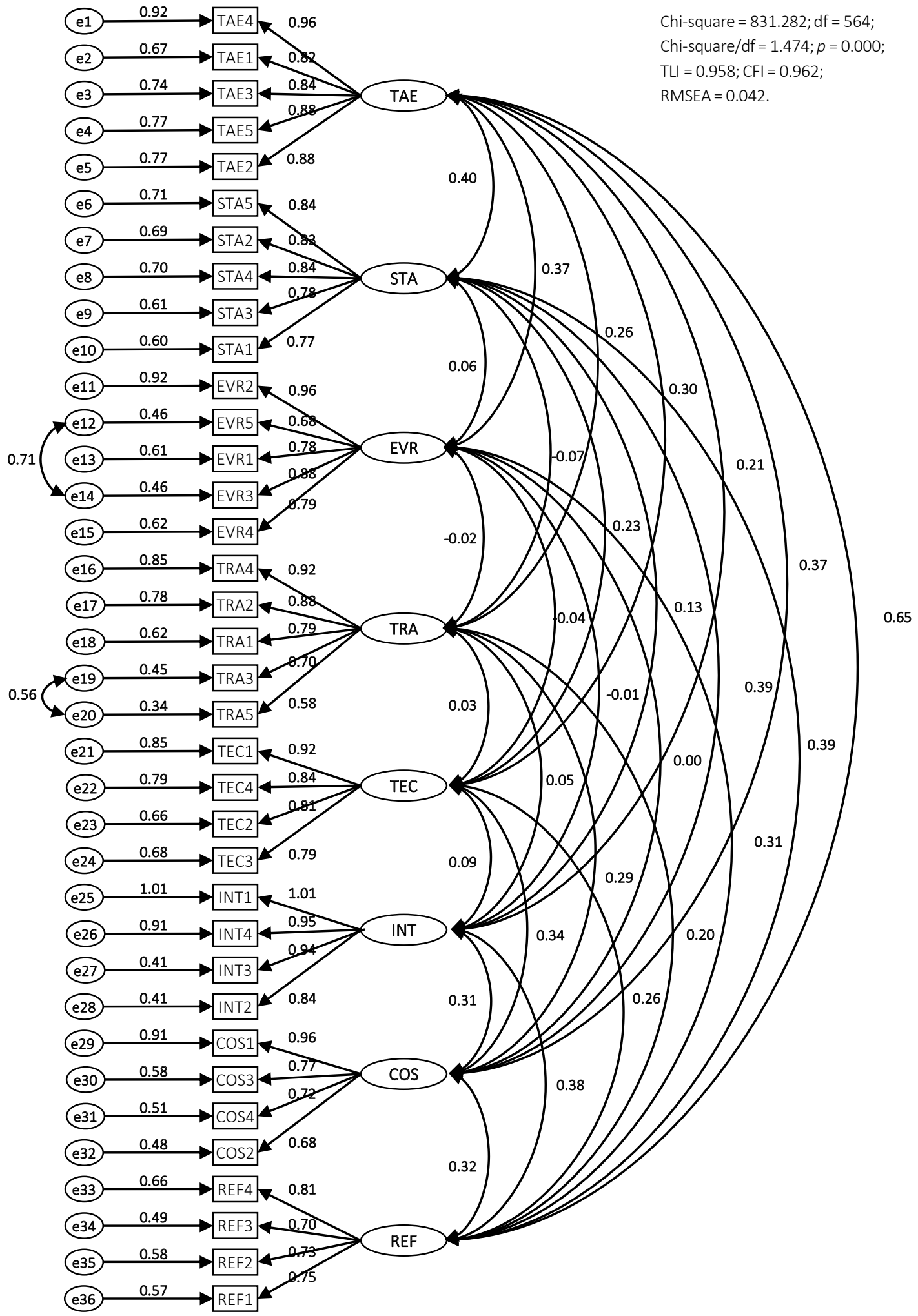

Figure 2. Testing of CFA (standardized estimates) 


\subsection{Model testing and hypotheses testing}

\subsubsection{Conceptual model testing}

The authors use SEM to test the conceptual model and other suggested hypotheses. The results from the testing show that the conceptual model has 579 degree of freedom $(p$-value $=0.000)$, Chisquare $/ \mathrm{df}=2.043<5, \mathrm{CFI}=0.915, \mathrm{TLI}=0.907$, and RMSEA $=0.063$, and $p<5 \%$. Therefore, the relationships between the concepts are confirmed theoretically.

\subsubsection{Hypotheses testing}

Table 5 shows that all 7 hypotheses initially suggested are accepted. This means that the accrual accounting reform in Vietnam is affected by 6 factors:

1) the accounting staff - especially their expertise, competence, and work experience;

2) training and support of consultants;

3) costs for accounting reform;

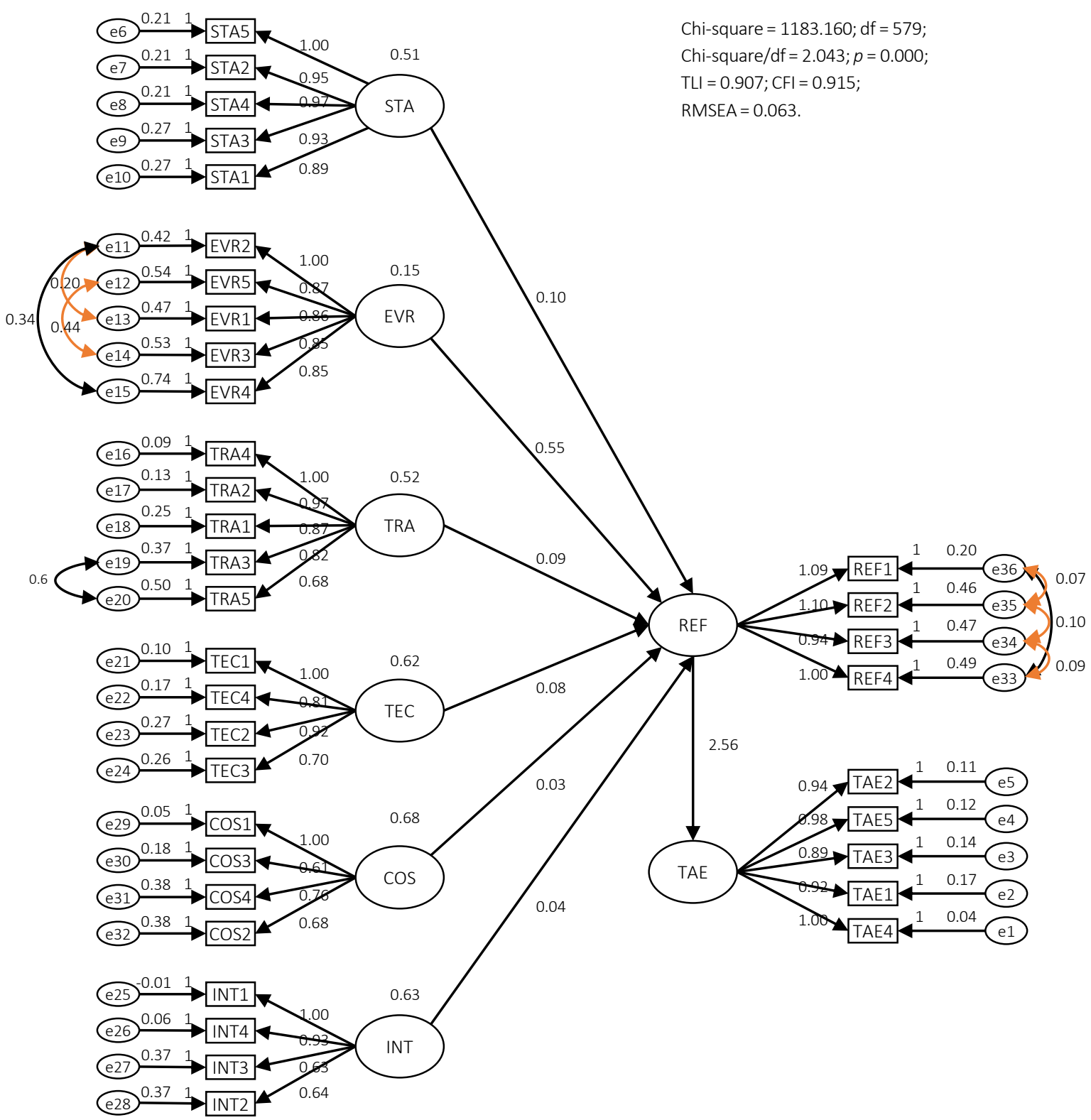

Figure 3. Testing of SEM (unstandardized estimates) 
Table 5. Results of hypotheses testing

\begin{tabular}{|c|c|c|c|c|c|}
\hline \multicolumn{6}{|c|}{ Source: Author's research (2019). } \\
\hline Relationship & Estimate & S.E. & C.R. & $\mathbf{P}$ & Label \\
\hline $\mathrm{REF} \leftarrow \mathrm{STA}$ & 0.102 & 0.020 & 5.094 & $* * *$ & H1 Accepted \\
\hline $\mathrm{REF} \leftarrow \mathrm{EVR}$ & 0.548 & 0.086 & 6.341 & $* * *$ & H6 Accepted \\
\hline$R E F \leftarrow$ TRA & 0.087 & 0.018 & 4.714 & $* * *$ & H2 Accepted \\
\hline$R E F \leftarrow T E C$ & 0.077 & 0.017 & 4.593 & $* * *$ & H4 Accepted \\
\hline $\mathrm{REF} \leftarrow \mathrm{INT}$ & 0.035 & 0.014 & 2.535 & 0.011 & H5 Accepted \\
\hline $\mathrm{REF} \leftarrow \mathrm{COS}$ & 0.031 & 0.014 & 2.239 & 0.025 & H3 Accepted \\
\hline $\mathrm{TAE} \leftarrow \mathrm{REF}$ & 2.555 & 0.296 & 8.618 & $* * *$ & H7 Accepted \\
\hline
\end{tabular}

Note: $* * * p<0.01$.

4) level of information technology application;

5) funding and assistance from international organizations;

6) legal environment.

The accrual-based accounting reform will have a positive impact on improving the transparency and efficiency or performance of public sector operations in Vietnam. Among the factors affecting accounting reform, the Legal environment (EVR) factor is the most influential determinant, followed by the contingent of accountants (see Table 6).

Table 6. Factors affecting the accrual accounting reform in Vietnam's public sector

Source: Author's research (2019).

\begin{tabular}{c|c|c|c}
\hline Relationship & Estimate & $\begin{array}{c}\text { Percentage, } \\
\%\end{array}$ & Rank \\
\hline REF $\leftarrow$ STA & 0.102 & 11.59 & 2 \\
\hline$R E F \leftarrow$ EVR & 0.548 & 62.27 & 1 \\
\hline$R E F \leftarrow$ TRA & 0.087 & 9.88 & 3 \\
\hline$R E F \leftarrow$ TEC & 0.077 & 8.75 & 4 \\
\hline$R E F \leftarrow$ INT & 0.035 & 3.97 & 5 \\
\hline$R E F \leftarrow$ COS & 0.031 & 3.54 & 6 \\
\hline Total & 0.88 & 100 & \\
\hline
\end{tabular}

\subsubsection{Testing the differences between samples}

Using quasi-independent samples $t$-test and one-way ANOVA analysis, the results are as follows: Table 7 shows some great differences between 2 groups of interviewees about the accrual accounting reform (because sig $=0.029$ $<0.05)$. The group of accountants and controllers has a stronger belief about the effect of factors on the accounting reform compared to the group of auditors. In the meantime, there are not many differences in the view of how the accrual accounting reform would affect the transparency and overall performance in the public sector $($ sig $=0.591>0.05)$.

Table 8 showed no difference between 2 groups of interviewees about the effect of the factors on the accounting reform ( $\mathrm{sig}=0.153>0.05$ ); however, male interviewees have a stronger belief that the accounting reform would affect the transparency and overall performance in the public sector.

Performing one-way ANOVA testing about the characteristics of interviewees related to age and

Table 7. Test results of the differences between 2 groups of interviewees

Source: Author's research (2019).

\begin{tabular}{|c|c|c|c|c|c|c|c|c|}
\hline & & \multicolumn{2}{|c|}{$\begin{array}{l}\text { Levene's test for } \\
\text { equality of variances }\end{array}$} & \multicolumn{5}{|c|}{$t$-test for equality of means } \\
\hline & & $\mathbf{F}$ & Sig. & $\mathbf{t}$ & df & $\begin{array}{c}\text { Sig. } \\
\text { (2-tailed) }\end{array}$ & $\begin{array}{c}\text { Mean } \\
\text { difference }\end{array}$ & $\begin{array}{l}\text { Std. error } \\
\text { difference }\end{array}$ \\
\hline \multirow{2}{*}{ REF } & Equal variances assumed & 4.831 & 0.029 & 0.064 & 266 & 0.949 & 0.00411 & 0.06465 \\
\hline & Equal variances not assumed & - & - & 0.055 & 70.431 & 0.956 & 0.00411 & 0.07451 \\
\hline \multirow{2}{*}{ TAE } & Equal variances assumed & 0.289 & 0.591 & 1.296 & 266 & 0.196 & 0.12426 & 0.09592 \\
\hline & Equal variances not assumed & - & - & 1.379 & 88.970 & 0.171 & 0.12426 & 0.09010 \\
\hline
\end{tabular}


Table 8. Test results of the differences between genders

Source: Author's research (2019).

\begin{tabular}{|c|c|c|c|c|c|c|c|c|}
\hline & & \multicolumn{2}{|c|}{$\begin{array}{l}\text { Levene's test for } \\
\text { equality of variances }\end{array}$} & \multicolumn{5}{|c|}{$t$-test for equality of means } \\
\hline & & $\mathbf{F}$ & Sig. & $\mathbf{t}$ & df & $\begin{array}{c}\text { Sig. } \\
\text { (2-tailed) }\end{array}$ & $\begin{array}{c}\text { Mean } \\
\text { difference }\end{array}$ & $\begin{array}{l}\text { Std. error } \\
\text { difference }\end{array}$ \\
\hline \multirow[b]{2}{*}{ REF } & Equal variances assumed & 2.051 & 0.153 & 3.402 & 266 & 0.001 & 0.17489 & 0.05141 \\
\hline & $\begin{array}{l}\text { Equal variances not } \\
\text { assumed }\end{array}$ & - & - & 3.410 & 243.419 & 0.001 & 0.17489 & 0.05130 \\
\hline \multirow[b]{2}{*}{ TAE } & Equal variances assumed & 15.467 & 0.000 & 5.132 & 266 & 0.000 & 0.38262 & 0.07455 \\
\hline & $\begin{array}{l}\text { Equal variances not } \\
\text { assumed }\end{array}$ & - & - & 5.216 & 254.256 & 0.000 & 0.38262 & 0.07335 \\
\hline
\end{tabular}

education level, the authors collected the results, showing no differences in the sample groups and their views on the factors affecting the accrual accounting reform in Vietnam's public sector.

\section{DISCUSSION}

Based on the above analysis, the results from this research have agreed with the researches of different authors such as Eriotis, Stamatiadis, and Vasiliou (2011), HassabElnaby, Epps, and Said (2003), Nasi and Steccolini (2008), Alshujairi (2014), Harun and Robinson (2010), Peter van der Hoek (2005), or Hien (2015) in Vietnam before 2014.

According to the research, the accrual accounting reform in the public sector in Vietnam is affected by many factors, of which the most important factor is the legal environment related to the reform. Therefore, in the coming years, Vietnam has to continuously adjust every legal issue in the public sector, especially the regulations related to the information published in the financial statements. Besides, Vietnam also should re-consider the regulations about managing public funding and public assets. This point of view is aligned with other authors' ideas, like Hien (2015) or Hai (2016).

The second most important factor affecting the accrual accounting reform in the public sector in Vietnam is the accounting staff. Therefore, in the future, education and training to improve the staff's expertise is critical and much needed. Vietnam needs to establish and execute an education program, improve and enhance the technical functions, and the accounting knowledge in the public sector using international accounting standards. This result completely agrees with the research of Ouda (2004), Eriotis, Stamatiadis, and Vasiliou (2011).

The accrual accounting reform is also influenced by different factors such as the information technology application, training, and assistance from the consultants, cost of the accrual process, funding, and assistance from other international organizations. These factors have a different effect, but they are all important in transforming the accounting system from cashbased to accrual-based. The results of this study are the same with the ideas of HassabElnaby, Epps, and Said (2003), Chan (2005), Upping and Oliver (2011), Harun, and Kamase (2012), Hien (2015). Therefore, to improve the accounting reform process, Vietnam should pay attention to investing in the infrastructure and IT application in accounting, replacing, or improving the accounting software, or the TABMIS system used in the past. Besides, calling for help and assistance from accounting experts, consultants, and investors is very helpful in executing the reforming process quickly.

The study also showed agreement with previous researches of Alijarde (1997), Ouda (2002), Paulsson (2006), Stamatiadis (2009), Lapsley, Mussari, and Paulsson (2009), Deaconu, Nistor, and Crina (2011), Lampe, Hilgers, and Ihl (2015). The accrual accounting reform from cash-based accounting, similar to the commercial and private industries, will improve the transparency, accounting responsibility, and the overall performance in the public sector. 


\section{CONCLUSION}

This research has determined the factors affecting the accounting reform from the cash-based accounting to accrual-based accounting in Vietnam's public sector. The factors' influences arranging from low to high are as follows: legal environment, accounting staff - their level of education, competencies, and working experience, training and assistance from consulting experts, level of information technology application, funding and assistance from international organization, and cost of the accounting reform. This research also proved that the accrual accounting reform has a strong effect on the transparency and overall performance in the public sector. There are still some limitations of this research: the new experimental investigation is only conducted with small sample size and in a short period, and the interviews were done only in some areas of Vietnam. Future research can focus on increasing the sample size and the time and places for the interview to get better results.

\section{AUTHOR CONTRIBUTIONS}

Conceptualization: Phuong-Nguyen Thi Thanh, Hai-Phan Thanh, Tung-Nguyen Thanh.

Formal analysis: Tung-Nguyen Thanh.

Funding acquisition: Phuong-Nguyen Thi Thanh, Tung-Nguyen Thanh.

Investigation: Hai-Phan Thanh, Tien-Vo Thi Thuy.

Methodology: Hai-Phan Thanh.

Project administration: Phuong-Nguyen Thi Thanh.

Resources: Phuong-Nguyen Thi Thanh, Hai-Phan Thanh, Tung-Nguyen Thanh.

Software: Hai-Phan Thanh.

Supervision: Phuong-Nguyen Thi Thanh.

Validation: Tien-Vo Thi Thuy.

Visualization: Tien-Vo Thi Thuy.

Writing - original draft: Phuong-Nguyen Thi Thanh, Hai-Phan Thanh, Tung-Nguyen Thanh, Tien-Vo Thi Thuy.

Writing - review \& editing: Phuong-Nguyen Thi Thanh, Hai-Phan Thanh, Tung-Nguyen Thanh, TienVo Thi Thuy.

\section{REFERENCES}

1. Alijarde, M. I. B. (1997). The Usefulness of Financial Reporting in Spanish Local Governments. Financial Accountability and Management, 13(1), 17-34. https:// doi.org/10.1111/1468-0408.00024

2. Alshujairi, M. H. A. (2014). Government Accounting System Reform and the Adoption of IPSAS in Iraq. Research Journal of Finance and Accounting, 5(24), 1-21. Retrieved from https://www. iiste.org/Journals/index.php/RJFA/ article/view/18490

3. Anderson, J. C., \& Gerbing, D. W. (1988). Structural equation modeling in practice: A review and recommended two-step approach. Psychological Bulletin, 103(3), 411423. https://doi.org/10.1037/00332909.103.3.411
4. Carlin, T. M. (2003). Accrual Accounting \& Financial Reporting in the Public Sector: Reframing the Debate (MGSM Working Papers Series No. WP 2003-22). Macquarie University. https://doi. org/10.2139/ssrn.473643

5. Chan, J. L. (2005). IPSAS and Government Accounting Reform in Developing Countries Title. Retrieved from http:// jameslchan.com/papers/ Chan2006IPSAS\&GAFDC.pdf

6. Deaconu, A., Nistor, C. S., \& Crina, F. (2011). The Impact of Accrual Accounting on Public Sector Management: An Exploratory Study for Romania. Transilvanian Review of Administrative Sciences, 32, 1-29. Retrieved from https:// ssrn.com/abstract $=1911285$
7. Eriotis, N., Stamatiadis, F., \& Vasiliou, D. (2011). Assessing Accrual Accounting Reform in Greek Public Hospitals: An Empirical Investigation. International Journal of Economic Sciences and Applied Research, 4(1), 153-184. Retrieved from https:// mpra.ub.uni-muenchen.de/30246/2/ MPRA_paper_30246.pdf

8. Hai, P. T., Tu, C. A., \& Toan, L. D. (2019). Research on factors affecting organizational structure, operating mechanism and audit quality: An empirical study in Vietnam. Journal of Business Economics and Management, 20(3), 526-545. https://doi.org/10.3846/ jbem.2019.9791

9. Hair, J. F., Black, W. C., Babin, B. J., Anderson, R. E., \& Tatham, R. L. 
(2006). Multivariate Data Analysis (6th ed.). NJ: Prentice Hall.

10. Harun, H., \& Kamase, $\mathrm{H}$. (2012). Accounting Change and Institutional Capacity: The Case of a Provincial Government in Indonesia. Australasian Accounting, Business and Finance Journal, 6(2), 35-50. Retrieved from https://ro.uow.edu.au/aabfj/ vol6/iss $2 / 4 /$

11. Harun, H., \& Robinson, P. (2010). The adoption of accrual accounting in the Indonesian public sector. Research in Accounting in Emerging Economies, 10, 233-250. https:// doi.org/10.1108/s14793563(2010)0000010014

12. HassabElnaby, H. R., Epps, R. W., \& Said, A. A. (2003). The impact of environmental factors on accounting development: an Egyptian longitudinal study. Critical Perspectives on Accounting, 14(3), 273-292. https://doi. org/10.1006/cpac.2002.0530

13. Hien, N. T. T. (2015). Improving the financial reporting in Vietnam's public sector [Hoàn thiện báo cáo tài chính khu vực công Việt Nam] (Doctoral Thesis). Ho Chi Minh University of Economics, Vietnam. (In Vietnamese)

14. Hong, L. T. C. (2013). Building and improving the financial reporting system using in public agencies in Vietnam, following the international accounting standards [Xây dựng và hoàn thiện hệ thống báo cáo tài chính áp dung cho đơn vị hành chính sư nghiệp ở Việt Nam theo định hướng chuân mưc kế toán công quốc tể. Ho Chi Minh University of Economics, Vietnam. (In Vietnamese)

15. Hooper, D., Coughlan, J., \& Mullen, M. R. (2008). Structural Equation Modelling: Guidelines for Determining Model Fit. Electronic Journal of Business Research Methods, 6(1), 53-60. Retrieved from http://mural. maynoothuniversity.ie/6596/1/JCStructural-Equation.pdf

16. Huy, P. Q. (2014). Improving the spending system in Vietnam's public sector [Hoàn thiện hệ thống kế toán thu chi ngân sách tại Việt Nam]
(Doctoral Thesis). Ho Chi Minh University of Economics, Vietnam. (In Vietnamese)

17. Jorge, S. M. F. (2003). Local government accounting in Portugal in comparative-international perspective (Doctoral Thesis). University of Birmingham. Retrieved from https://estudogeral. sib.uc.pt/bitstream/10316/13545/1/ tese.pdf

18. Jovanović, T. (2013). Public sector accounting reform. Paper presented at 21st NISPAcee Annual Conference Regionalisation and Inter-Regional Cooperation (pp. 1-13). Retrieved from http://www. nispa.org/files/conferences/2013/ papers/201304102049310.Public\%20sector\%20accounting\%20 reform-Jovanovi\%C4\%87.pdf

19. Lampe, H. W., Hilgers, D., \& Ihl, C (2015). Does accrual accounting improve municipalities' efficiency? Evidence from Germany. Applied Economics, 47(41), 4349-4363. https://doi.org/10.1080/00036846. 2015.1030562

20. Lapsley, I., Mussari, R., \& Paulsson, G. (2009). On the Adoption of Accrual Accounting in the Public Sector: A SelfEvident and Problematic Reform. European Accounting Review, 18(4), 719-723. https://doi. org/10.1080/09638180903334960

21. Lüder, K. (1992). A contingency model of governmental accounting innovations in the politicaladministrative environment. Research in Governmental and Non-Profit Accounting, 7, 99-127. Retrieved from http://jameslchan. com/papers/Luder1992ContingencyModel.pdf

22. Nasi, G., \& Steccolini, I. (2008) Implementation of accounting reforms. Public Management Review, 10(2), 175-196. https://doi. org/10.1080/14719030801928573

23. Nistor, C. S., Deaconu, A., \& Mare, C. (2014). Influence of environmental factors on the evolution of Romanian public accounting. Journal of Business Economics and Management, 16(6), 1154-1169. https://doi.org/10.3846 /16111699.2013.804872
24. Nunnally, J. C. (1978). Psychometric theory (2nd ed.). New York: McGraw-Hill.

25. Ouda, H. A. G. (2004). Basic Requirements Model for Successful Implementation of Accrual Accounting in the Public Sector. Public Fund Digest, 4(1), 78-99. Retrieved from http:// www.unsceb.org/system/files/Fi nance $\% 20 \% 26 \% 20$ Budget $\% 20$ Network/Accounting\%20Standards/ fold31069/ipsasguide/ipsasguide3. pdf\#page $=78$

26. Ouda, H. A. G. (2008), Transition barriers of accrual accounting in the public sector of developed and developing countries: statistical analyses with special focus on the Netherlands and Egypt. In S. Jorge (Ed.), Implementing reforms in public sector accounting. Imprensa da Universidade de Coimbra. http://dx.doi.org/10.14195/978989-26-0422-0_5

27. Paulsson, G. (2006). Accrual Accounting in the Public Sector: Experiences from the Central Government in Sweden Financial Accountability and Management, 22(1), 47-62. https://doi.org/10.1111/j.02674424.2006.00392.x

28. Peter Van der Hoek, M. (2005). From Cash to Accrual Budgeting and Accounting in the Public Sector: The Dutch Experience. Public Budgeting Finance, 25(1), 32-45. https://doi.org/10.1111/ j.0275-1100.2005.00353.x

29. Peterson, R. A. (1994). A MetaAnalysis of Cronbach's Coefficient Alpha. Journal of Consumer Research, 21(2), 381-391. https:// doi.org/10.1086/209405

30. Scapens, R. W., \& Jazayeri, M. (2003). ERP systems and management accounting change: opportunities or impacts? A research note. European Accounting Review, 12(1), 201-233. https://doi.org /10.1080/0963818031000087907

31. Schumacker, R. E., \& Lomax, R. G. (2004). A beginner's guide to structural equation modeling (2nd ed.). Lawrence Erlbaum Associates, Publishers, Mahwah, New Jersey, London. 
32. Stamatiadis, F. (2009).

Governmental accounting reform in the Greek public hospitals: Some preliminary results of its implementation. Paper presented at 4th Hellenic Observatory $P h D$ Symposium. London School of Economics and Political Science. Retrieved from http://www.lse. ac.uk/europeanInstitute/research/ hellenicObservatory/pdf/4th_\%20 Symposium/PAPERS_PPS/BUSINESS\%20\%20FINANCE/STAMATIADIS.pdf

33. Stamatiadis, F., \& Eriotis, N. (2011). Evolution of the Governmental Accounting Reform
Implementation in Greek Public Hospitals: Testing the Institutional Framework. Paper presented at 34th Annual Congress of the European Accounting Association. Retrieved from https://ssrn.com/ abstract $=1760423$

34. The Vietnam Ministry of Finance. (2019). Curricular No. 1299/QDBTC date 31/07/2019 approved the proposal for issuing the accounting standards for public sector in Vietnam. [Quyết đinh số 1299/ QĐ-BTC ngày 31/07/2019 phê chuân đề án công bố hệ thống chuân mực kế toán công Việt Nam]. (In Vietnamese). Retrieved from https://luatvietnam.vn/ke-toan/ quyet-dinh-1299-qd-btc-2019-dean-cong-bo-he-thong-chuan-mucke-toan-cong-viet-nam-175849-d1. html

35. Upping, P., \& Oliver, J. (2011). Accounting change model for the public sector: adapting Luder's model for developing countries. International Review of Business Research Papers, 7(1), 364-380. Retrieved from https://www.researchgate.net/ publication/228614303_Accounting_Change_Model_for_the_Public_Sector_Adapting_Luder\%27s Model_for_Developing_Countries 